\title{
Aplikasi Direct Matrix Converter pada Pengendali Kecepatan Motor Induksi 3 Fase menggunakan Modulasi Venturini
}

\section{GAMAR BASUKI, ERA PURWANTO, HARY OKTAVIANTO, MENTARI PUTRI JATI, MOCHAMAD ARI BAGUS NUGROHO}

\author{
Teknik Elektro Politeknik Elektronika Negeri Surabaya, Indonesia \\ Email: gamarbasuki@gmail.com
}

Received 24 Januari 2020 | Revised 23 Februari 2020 | Accepted 25 Juni 2020

\begin{abstract}
ABSTRAK
Motor induksi yang paling banyak digunakan juga memiliki kekurangan seperti losses yang cukup tinggi, power factor correction, dan efisiensi yang rendah. Oleh karena itu, dibutuhkan pengendali motor induksi yang memiliki performa dan efisiensi yang tinggi. Salah satu jenis AC - AC konverter yang mempunyai efisiensi, lifetime, kekompakan dan faktor daya mendekati unity yang akan digunakan sebagai pengendali motor induksi adalah matrix converter. Metode venturini digunakan sebagai modulasi pada matrix converter. Untuk itu dalam penelitian ini dilakukan pembuatan simulasi menggunakan simulink MATLAB dan hardware matrix converter. Pengujian matrix converter menggunakan modulasi venturini sebagai pengendali motor induksi telah dilakukan dengan motor dapat berputar mencapai kecepatan nominal sebesar 1440 Rpm sesuai nameplate dan motor juga dapat berputar dibawah frekuensi nominal. Dengan penelitian ini, pengendalian motor induksi dapat lebih efisien dalam penggunaannya di berbagai bidang.
\end{abstract}

Kata kunci: Matrix converter, metode venturini, motor induksi.

\begin{abstract}
The most widely used induction motors also have disadvantages such as fairly high losses, power factor correction, and low efficiency. From this disadvantages, we need an induction motor controller that has high performance and efficiency. One type of AC-AC converter that has efficiency, lifetime, compactness and power factor approach to unity that will be used as an induction motor controller is a matrix converter. The Venturini method is used as modulation in the matrix converter. For this reason, in this study, simulation was made using MATLAB simulink and hardware matrix converter. Matrix converter testing using venturini modulation as an induction motor controller has been done with the motor can be rotate reaching a nominal speed of $1440 \mathrm{Rpm}$ according to nameplate and the motor can also rotate below the nominal frequency. It is expected that induction motor controller can be more efficient in their use in various fields.
\end{abstract}

Keywords: Matrix converter, venturini method, induction motor 


\section{PENDAhUlUAN}

Motor listrik yang paling banyak digunakan adalah jenis motor induksi dengan pertimbangan beberapa faktor yaitu struktur yang simpel, volume kecil, harga yang murah, pengemudian elektrik yang mudah dan fleksible, efisiensi dan power density yang tinggi, memiliki torsi awal yang tinggi, range torsi dan daya konstan yang luas, memiliki respon torsi yang andal dalam beberapa kondisi operasi, dan lain - lain (Riba, dkk, 2016). Menurut Saqib Jamshed Rind dan kawan - kawan yang dipublikasikan dalam Chinese Journal of Electrical Engineering 2017 membahas tentang evaluasi perbandingan performa beberapa jenis motor penggerak kendaraan listrik dapat diketahui bahwa motor induksi merupakan pilihan dengan penilaian yang paling tinggi untuk digunakan sebagai penggerak berdasarkan pertimbangan beberapa faktor seperti yang tertera pada Tabel 1.

Tabel 1. Evaluasi Performa Beberapa Jenis Motor Penggerak

\begin{tabular}{|c|c|c|c|c|}
\hline Karakteristik motor & DC & IM & PMSM & SRM \\
\hline Kekuatan daya & 2.5 & 4 & 5 & 3.5 \\
\hline Efisiensi & 2.5 & 4 & 5 & 4.5 \\
\hline Sistem kontrol & 5 & 5 & 4 & 3 \\
\hline Keandalan & 3 & 5 & 4 & 5 \\
\hline Kekokohan & 3 & 5 & 4 & 5 \\
\hline Kekuatan torsi & 3 & 4 & 5 & 4 \\
\hline Jarak kecepatan & 2.5 & 4 & 4.5 & 4.5 \\
\hline Pemeliharaan & 3 & 4 & 4 & 4 \\
\hline Riak/gangguan torsi & 3.5 & 4.5 & 4.5 & 3 \\
\hline Kemampuan beban lebih & 3 & 4 & 4 & 4 \\
\hline Kekuatan teknis & 5 & 4.5 & 4 & 3.5 \\
\hline Daya tahan & 3.5 & 5 & 4 & 4.5 \\
\hline Ukuran dan berat & 3 & 4 & 5 & 4 \\
\hline Harga & 4 & 5 & 3 & 4 \\
\hline Total & 46.5 & 62 & 60 & 56.5 \\
\hline
\end{tabular}

Disamping memiliki beberapa keunggulan dalam beberapa faktor yang telah dibahas sebelumnya, motor induksi juga memiliki beberapa kelemahan, yaitu losses yang cukup tinggi, power factor dan efisiensi yang rendah (Hannan, dkk, 2017).

Dari penjabaran tentang kekurangan motor induksi tersebut, maka dibutuhkan pengendali motor induksi yang memiliki performa dan efisiensi yang tinggi. Secara umum, untuk mengendalikan kecepatan motor induksi 3 fase dapat dilakukan dengan cara mengubah tegangan atau frekuensi masukan menggunakan konverter konvensional seperti inverter. PWM yang digunakan pada inverter dapat menyebabkan rugi - rugi switching karena frekuensi yang tinggi dan menyebabkan timbulnya harmonisa orde tinggi. Selain itu, PWM dari inverter juga dapat meningkatkan daya reaktif ketika torsi turun dan mempengaruhi efisiensi motor. Sehingga sangatlah penting untuk memperhitungkan efek dari losses akibat PWM yang dihasilkan inverter dalam merancang motor (Fujisaki, Sakai, \& Takeda, 2012).

Telah banyak penelitian yang membahas tentang $\mathrm{AC}-\mathrm{AC}$ konverter yang mempunyai efisiensi, lifetime, struktur dan faktor daya mendekati unity menggunakan matrix converter (Hamane, Doumbia, Cheriti, \& Belmokhtar, 2014). Matrix converter merupakan konverter single state yang memiliki susunan $\mathrm{m}$ ke $\mathrm{n}$ sakelar bidirectional secara langsung menghubungkan 
sumber tegangan masukan fase $\mathrm{m}$ ke beban fase $\mathrm{n}$ tanpa membutuhkan elemen penyimpanan energi (Karaca \& Akkaya, 2012) (Mahendra \& Gurusamy, 2010). Salah satu jenis modulasi switching pada matrix converter yang digunakan dikenal sebagai metode Venturini atau pendekatan direct transfer function. Dalam metode ini, sinyal untuk penggerak gerbang sembilan sakelar bidirectiona/dihitung untuk menghasilkan tegangan keluaran sinusoidal.

Dalam makalah ini mengajukan sebuah perancangan matrix converter sebagai penggerak dari motor induksi menggunakan metode Venturini sebagai teknik modulasinya. Hasil tegangan keluaran sinusoidal dari matrix converter digunakan sebagai sumber tegangan masukan dari motor induksi 3 fase. Sementara itu, tujuan dari perancangan direct matrix converter diharapkan dapat melakukan pengendalian kecepatan motor induksi 3 fase dengan tegangan keluaran yang dapat menghasilkan perubahan frekuensi, menghasilkan efisiensi yang bagus dan losses yang rendah.

\section{METODOLOGI PENELITIAN}

\subsection{Simulasi Direct Matrix Converter pada Motor Induksi 3 Fase}

Pada penelitian ini yang menjadi salah satu bagian penting adalah pembuatan dan perencanaan matrix converter dan metode Venturini. Simulasi matrix converter terdiri dari 9 sakelar bidirectional dan telah di simulasikan menggunakan Simulink pada software MATLAB seperti pada Gambar 1.

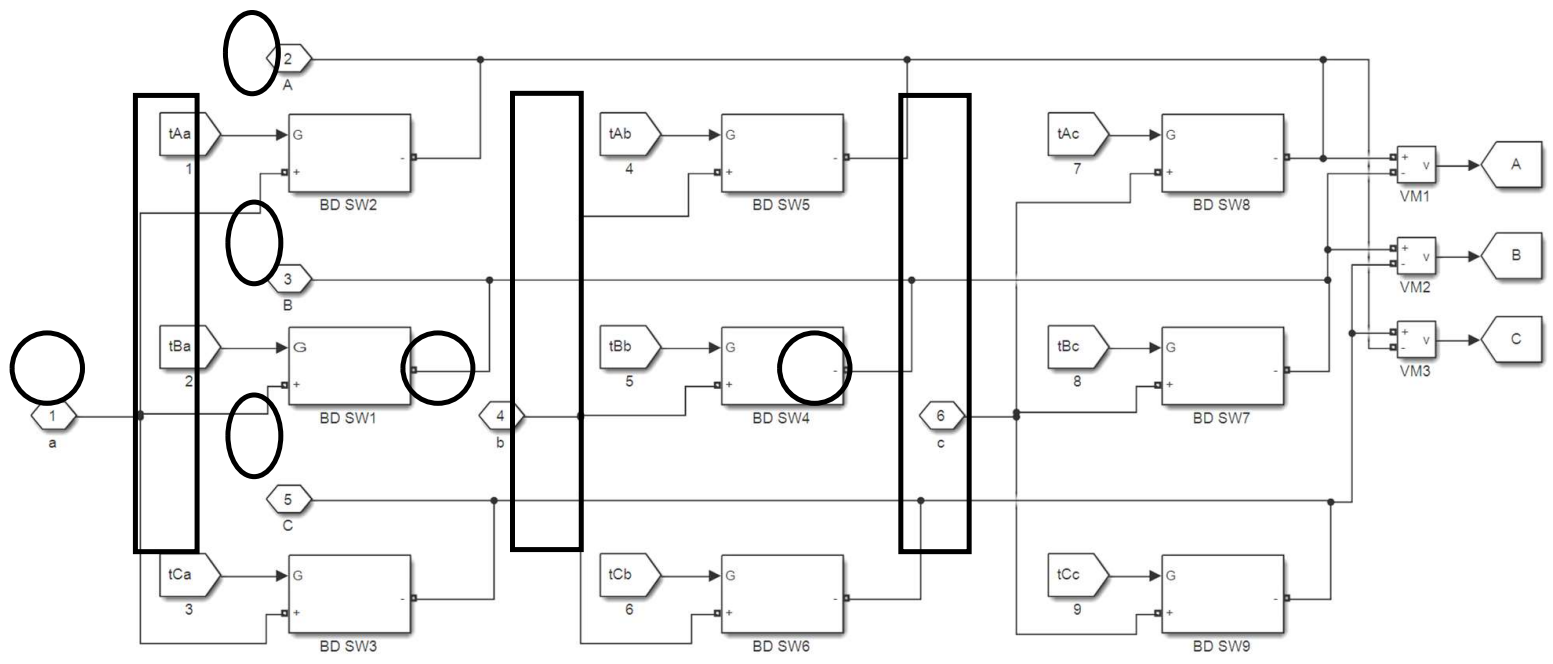

Gambar 1. Sembilan Sakelar Bidirectional Matrix Converter

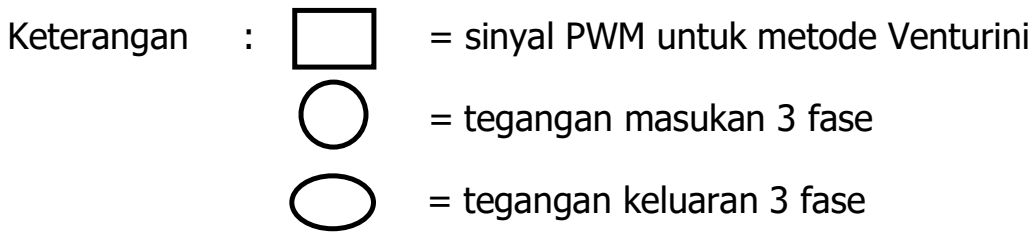

Topologi 9 sakelar dua arah pada matrix converter dapat difungsikan pada frekuensi tinggi, sedangkan tujuan utama dari konverter ini adalah menghasilkan tegangan keluaran 3 fase dan frekuensi mengikuti karakteristik dari keluaran yang di inginkan. Dengan 9 sakelar bidirectional matrix converter dapat diasumsikan secara teori memiliki $512\left(2^{9}\right)$ kombinasi switching yang berbeda (Roy, dkk, 2017), tetapi tidak semua dapat digunakan. Kombinasi switching yang 
dapat digunakan dalam matrix converter memiliki beberapa aturan yaitu (Bachir \& Bendiabdellah, 2009):

1) 3 buah sakelar yang terhubung dalam 1 kombinasi

2) Fase masukan tidak terhubung singkat.

3) Hanya 1 sakelar yang terhubung pada setiap fase.

Dari batasan tersebut, maka pada matrix converter $3 \times 3$ ini terdapat 27 kombinasi switching yang diperbolehkan.

Persamaan matematis dari vektor tegangan masukan dapat di tuliskan seperti pada Persamaan (1).

$$
\left|V_{i}\right|=V_{i m}\left[\begin{array}{c}
\cos \omega_{i} t \\
\cos \left(\omega_{i} t-\frac{2 \pi}{3}\right) \\
\cos \left(\omega_{i} t-\frac{4 \pi}{3}\right)
\end{array}\right]
$$

Sementara itu untuk persamaan matematis vektor tegangan keluaran dapat dituliskan seperti Persamaan (2).

$$
\left|V_{o}\right|=V_{o m}\left[\begin{array}{c}
\cos \omega_{o} t \\
\cos \left(\omega_{o} t-\frac{2 \pi}{3}\right) \\
\cos \left(\omega_{o} t-\frac{4 \pi}{3}\right)
\end{array}\right]
$$

Hubungan antara tegangan keluaran dan tegangan masukan ditunjukkan oleh Persamaan (3).

$$
\left[V_{o}\right]=[M]\left[V_{i}\right]
$$

Dimana [M] adalah matriks modulasi. Sementara itu, untuk hubungan arus masukan dan arus keluaran ditunjukkan oleh Persamaan (4).

$$
\left[I_{i}\right]=[M]^{T}\left[I_{o}\right]
$$

Dan $[\mathrm{M}]^{\top}$ adalah transpose matriks dari matriks modulasi $[\mathrm{M}]$. Fungsi modulasi dari matriks [M] adalah seperti pada Persamaan (5).

$$
\vec{M}=\left[\begin{array}{lll}
m_{11}(t) & m_{12}(t) & m_{13}(t) \\
m_{21}(t) & m_{22}(t) & m_{23}(t) \\
m_{31}(t) & m_{32}(t) & m_{33}(t)
\end{array}\right]
$$

Perhitungan matematis dari direct matrix converter dijelaskan oleh Persamaan (1), Persamaan (2), Persamaan (3), Persamaan (4), dan Persamaan (5). Sementara itu, untuk parameter yang digunakan pada hasil simulasi ditunjukkan pada Tabel 2 . Nilai parameter yang terdapat pada Tabel 2 akan menjadi rujukan untuk melakukan pengujian.

Tabel 2. Parameter Simulasi Sistem

\begin{tabular}{|c|c|}
\hline Tegangan masukan (Volt) & $220 \mathrm{~V}$ L-L \\
\hline $\begin{array}{c}\text { q (ratio tegangan } \\
\text { masukan keluaran) }\end{array}$ & 0,5 \\
\hline Frekuensi masukan $(\mathrm{Hz})$ & $50 \mathrm{~Hz}$ \\
\hline Frekuensi keluaran $(\mathrm{Hz})$ & $40 \mathrm{~Hz} \mathrm{dan} 50 \mathrm{~Hz}$ \\
\hline Frekuensi switching $(\mathrm{Hz})$ & $6 \mathrm{kHz}$ \\
\hline Beban motor $(\mathrm{HP} / \mathrm{kW})$ & Motor induksi $3 \varnothing 10 \mathrm{HP}$ \\
\hline
\end{tabular}


Bentuk gelombang keluaran hasil dari simulasi matrix converter ditunjukkan pada Gambar 2.

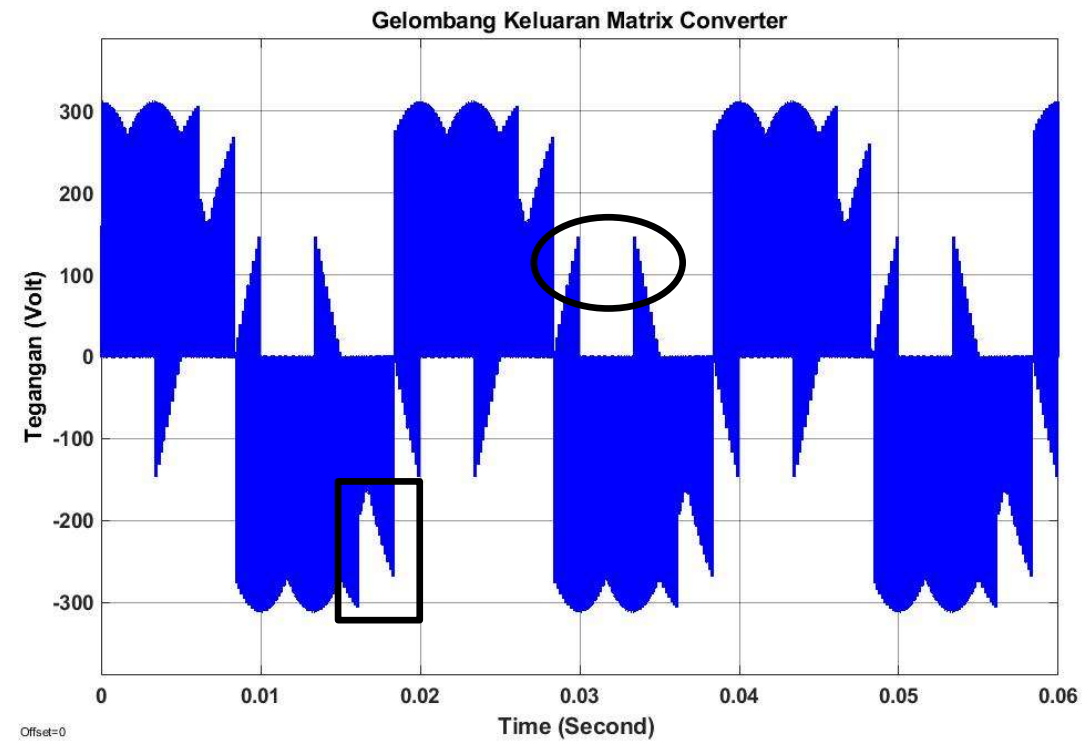

Gambar 2. Gelombang Tegangan Keluaran Matrix Converter dengan q = 0,5

Keterangan:

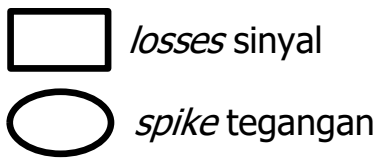

Gambar 2 adalah bentuk gelombang keluaran dari direct matrix converter. Bentuk gelombang keluaran tersebut masih terdapat spike tegangan pada saat sinyal menyentuh nilai 0 dan ada juga terjadi losses sinyal. Hal ini bisa terjadi salah satu penyebabnya adalah karena beban motor induksi yang digunakan dapat menimbulkan harmonisa. Hasil simulasi pada Gambar 2 akan dijadikan sebagai rujukan untuk menguji hardware dari matrix converter. Sementara itu, respon kecepatan dari penggunaan direct matrix converter pada pengendali kecepatan motor induksi 3 fase ditunjukkan pada Gambar 3.

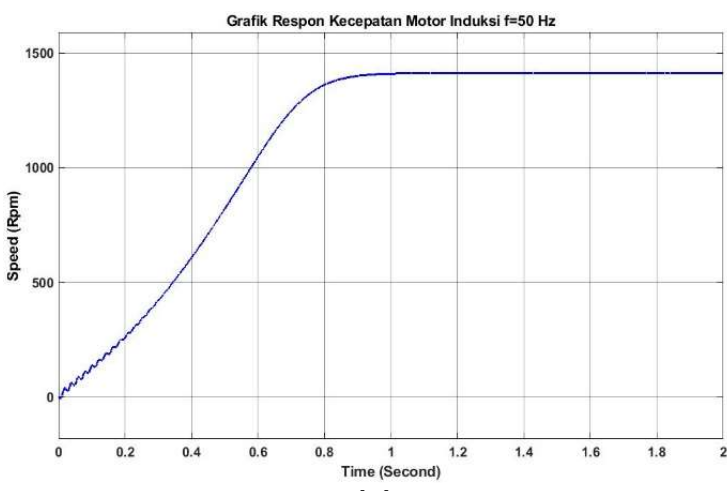

(a)

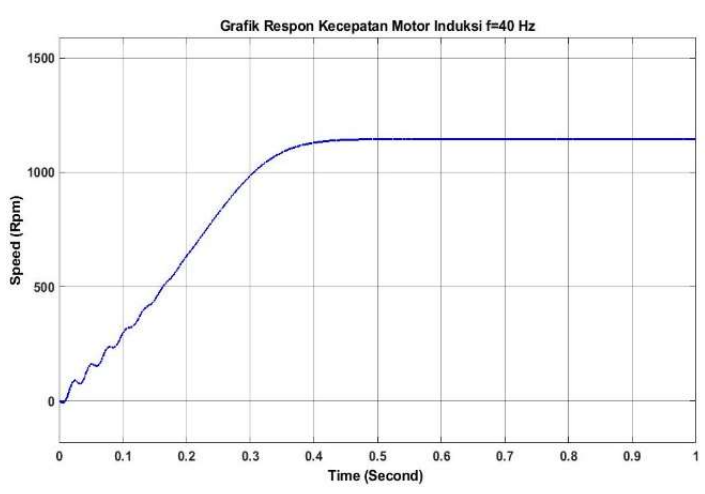

(b)

Gambar 3. Respon Kecepatan Motor Induksi (a) $f_{\text {out }}=50 \mathrm{~Hz}$ (b) $f_{\text {out }}=40 \mathrm{~Hz}$ 


\subsection{Perancangan Hardware Direct Matrix Converter}

Direct Matrix converter adalah konverter yang memiliki susunan baris dan kolom sakelar bidirectional yang secara langsung menghubungkan sumber tegangan masukan fase-m ke beban fase-n (Karaca \& Akkaya, 2012), (Mahendra \& Gurusamy, 2010). Konverter ini adalah konverter AC-AC langsung tanpa membutuhkan perubahan dari AC ke DC atau sebaliknya. Rangkaian dari matrix converter dapat dilihat pada Gambar 4.

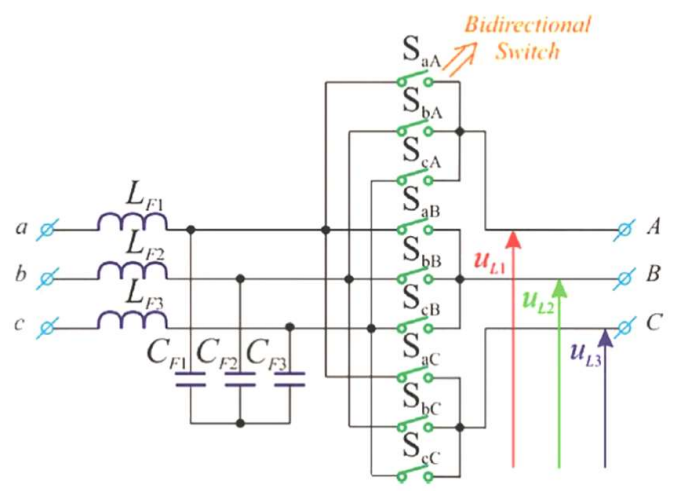

Gambar 4. Rangkaian Matrix Converter 3 Fase

Setelah pembahasan tentang direct matrix converter, langkah selanjutnya akan dibuat perancangan hardware dari direct matrix converter menggunakan MOSFET tipe IXFH 60N60. MOSFET dengan tipe IXFH60N60 yang dihubungkan secara Common Emitter untuk memungkinkan arus dapat mengalir secara bolak balik. Pemilihan MOSFET tipe tersebut dikarenakan memiliki tegangan kerja $\left(V_{D S}\right)$ yang besar yakni 600 Volt dan arus $\left(\mathrm{I}_{\mathrm{D}}\right)$ sebesar 60A pada kondisi continuous dan 200A pada kondisi impulsed sehingga menjadikan MOSFET ini dapat digunakan pada direct matrix converter yang beroperasi pada tegangan $\left(\mathrm{V}_{\mathrm{rms}}\right) 380$ Volt dengan tegangan puncak $\left(V_{\max }\right)$ sebesar 538 Volt. Dengan kemampuan tersebut, MOSFET diharapkan memiliki daya tahan yang baik dan dapat mengalirkan arus secara dua arah pada saat dioperasikan pada sistem yang dirancang. Gambar 5 adalah sakelar bidirectional yang terdiri dari 2 MOSFET yang dihubungkan secara berkebalikan untuk proses konversi daya pada direct matrix converter.

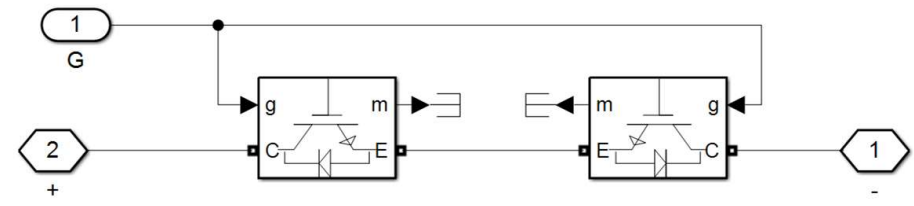

\section{Gambar 5. Sakelar Bidirectiona/ Menggunakan MOSFET}

Sakelar bidirectional pada Gambar 5 dirancang menggunakan MOSFET tipe IXFH 60N60 dan terdiri dari 9 buah sakelar yang masing - masing sakelar bidirectiona/ akan diberikan sinyal PWM melalui perhitungan matematis menggunakan metode Venturini. Dari hasil perhitungan matematis untuk sinyal PWM akan dihubungkan ke kaki Gate dari MOSFET. Dengan mengikuti aturan untuk proses modulasi switching pada direct matrix converter, maka hasil keluaran pada direct matrix converter akan menghasilkan tegangan keluaran yang nilai frekuensinya tetap maupun frekuensinya berubah.

\subsection{Metode Venturini}

Dalam metode Venturini, tegangan keluaran tiga fase yang diinginkan dapat disintesis dari rangkaian tegangan sinusoidal masukan tiga fase yang di suplai secara berurutan. Bentuk 
gelombang tegangan keluaran karena itu terdiri dari bagian gelombang tegangan masukan. Oleh karena itu, penentuan sinyal PWM yang tepat untuk masing - masing dari 9 sakelar bidirectional harus dihitung secara matematis untuk menghasilkan perubahan frekuensi atau perubahan tegangan keluaran sinusoidal dari frekuensi tetap dan tegangan masukan tetap (Rezaoui, Kouzou, Nezli and Mahmoudian, 2013). Persamaan matematis untuk hubungan tegangan masukan dan tegangan keluaran serta arus masukan dan arus keluaran ditulis seperti pada Persamaan (6) dan Persamaan (7).

$$
\begin{aligned}
& {\left[\begin{array}{l}
V_{A}(t) \\
V_{B}(t) \\
V_{C}(t)
\end{array}\right]=\left[\begin{array}{lll}
m_{11}(t) & m_{12}(t) & m_{13}(t) \\
m_{21}(t) & m_{22}(t) & m_{23}(t) \\
m_{31}(t) & m_{32}(t) & m_{33}(t)
\end{array}\right]\left[\begin{array}{l}
V_{a}(t) \\
V_{b}(t) \\
V_{c}(t)
\end{array}\right]} \\
& {\left[\begin{array}{l}
I_{a}(t) \\
I_{b}(t) \\
V_{c}(t)
\end{array}\right]=\left[\begin{array}{lll}
m_{11}(t) & m_{21}(t) & m_{31}(t) \\
m_{12}(t) & m_{22}(t) & m_{32}(t) \\
m_{13}(t) & m_{23}(t) & m_{33}(t)
\end{array}\right]\left[\begin{array}{l}
I_{A}(t) \\
I_{B}(t) \\
I_{C}(t)
\end{array}\right]}
\end{aligned}
$$

Setiap fungsi modulasi dari matriks $[\mathrm{M}], \mathrm{m}_{\mathrm{ij}}(\mathrm{t})(\mathrm{I}, \mathrm{j}=1,2,3)$, merepresentasikan nilai duty cycle dari masing - masing sakelar bidirectional selama periode sampling $\mathrm{T}_{\mathrm{s}}$ dan fungsi dari duty cycle pada matriks [M] nilainya terbatas, yaitu antara $0<\mathrm{m}_{\mathrm{ij}}(\mathrm{t})<1(\mathrm{I}, \mathrm{j}=1,2,3)$ (Metidji, dkk, 2013). Sementara itu, perhitungan untuk waktu modulasi Venturini pada fase pertama ditunjukkan pada Persamaan (8), (9), dan (10) (Kandan, Senthilkumar dan Dhivya, 2016).

$$
\begin{aligned}
& t_{11}=\frac{T_{s}}{3}\left(1+2 q \cos \left(\omega_{m} t+\theta\right)\right) \\
& t_{12}=\frac{T_{s}}{3}\left(1+2 q \cos \left(\omega_{m} t+\theta-\frac{2 \pi}{3}\right)\right) \\
& t_{13}=\frac{T_{s}}{3}\left(1+2 q \cos \left(\omega_{m} t+\theta-\frac{4 \pi}{3}\right)\right)
\end{aligned}
$$

Perhitungan waktu modulasi fase kedua ditunjukkan oleh Persamaan (11), Persamaan (12), dan Persamaan (13).

$$
\begin{aligned}
& t_{21}=\frac{T_{s}}{3}\left(1+2 q \cos \left(\omega_{m} t+\theta-\frac{4 \pi}{3}\right)\right) \\
& t_{22}=\frac{T_{s}}{3}\left(1+2 q \cos \left(\omega_{m} t+\theta\right)\right) \\
& t_{23}=\frac{T_{s}}{3}\left(1+2 q \cos \left(\omega_{m} t+\theta-\frac{2 \pi}{3}\right)\right)
\end{aligned}
$$

Dan untuk perhitungan modulasi fase ketiga ditunjukkan oleh Persamaan (14), Persamaan (15), dan Persamaan (16).

$$
\begin{aligned}
& t_{31}=\frac{T_{s}}{3}\left(1+2 q \cos \left(\omega_{m} t+\theta-\frac{4 \pi}{3}\right)\right) \\
& t_{32}=\frac{T_{s}}{3}\left(1+2 q \cos \left(\omega_{m} t+\theta-\frac{2 \pi}{3}\right)\right) \\
& t_{33}=\frac{T_{s}}{3}\left(1+2 q \cos \left(\omega_{m} t+\theta\right)\right)
\end{aligned}
$$

Proses untuk membangkitkan sinyal PWM yang dihitung menggunakan metode Venturini dihasilkan dari sebuah mikrokontroller arm STM32 F407VGTX yang diprogram dari 
MATLAB/Simulink. Hasil tegangan keluaran dari mikrokontroller memiliki nilai tegangan antara 0 - 3.3 Volt, dimana sinyal yang dihasilkan adalah sinyal PWM yang sudah melalui proses modulasi. Tegangan keluaran dari mikrokontroller tidak bisa langsung digunakan untuk menggerakkan gerbang Gate dari MOSFET, karena nilai tegangannya tidak memenuhi syarat untuk menggerakkan gerbang Gate dari MOSFET. Maka dari itu, diperlukan sebuah penguatan sinyal tanpa mengubah bentuk dari sinyal itu sendiri dengan menggunakan sebuah komponen IC FOD3182. Tegangan keluaran dari IC FOD3182 dapat digunakan untuk menggerakkan gerbang Gate dari MOSFET, karena MOSFET dapat berfungsi jika kaki Gate dari MOSFET mendapatkan sinyal tegangan $>10$ Volt. Gambar 6 adalah rangkaian yang digunakan untuk menggerakkan gerbang kaki Gate dari MOSFET.

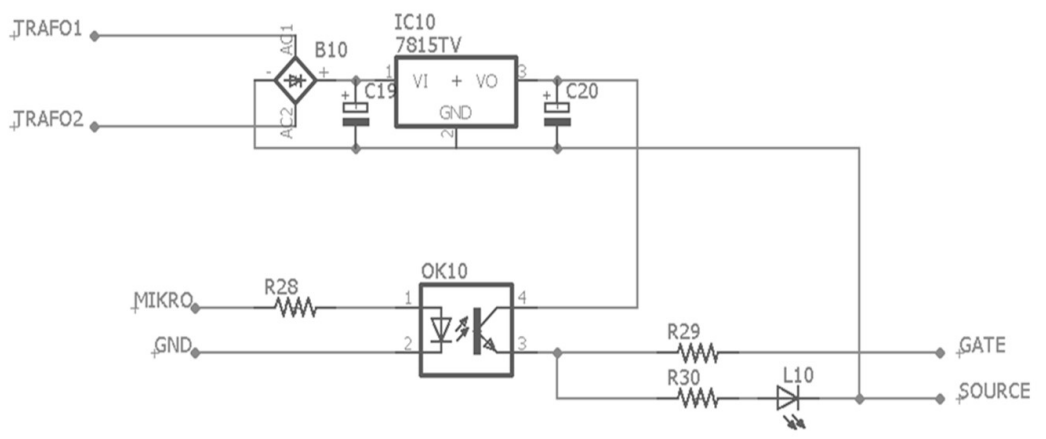

Gambar 6. Driver MOSFET menggunakan IC FOD3182

\section{PENGUJIAN DAN ANALISIS}

\subsection{Pengujian Metode Venturini}

Perancangan dan pengujian matrix converter sebagai pengendali motor induksi 3 fase diawali dengan membuat simulasi menggunakan simulink/MATLAB. Dari hasil simulasi akan dijadikan sebagai rujukan untuk melakukan pengujian hardware direct matrix converter. Sementara itu, diagram blok pengujian hardware dari direct matrix converter dapat dilihat pada Gambar 7.

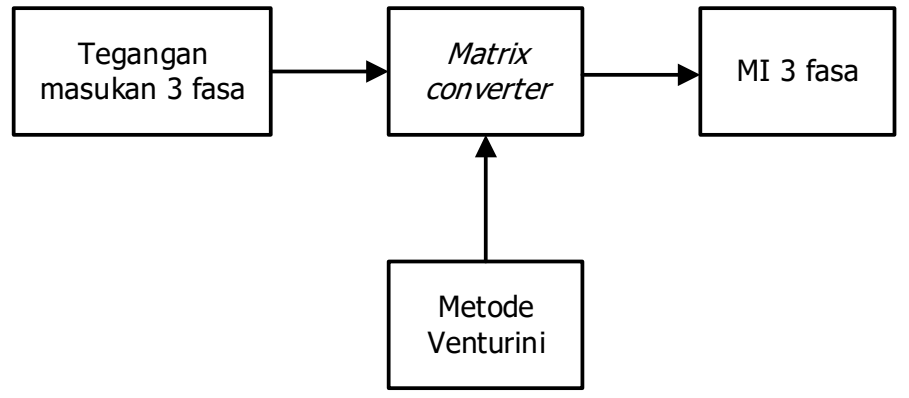

\section{Gambar 7. Diagram Blok Pengujian Matrix Converter}

Metode Venturini adalah salah satu teknik modulasi yang paling sering digunakan pada matrix converter selain dari teknik modulasi SVM. Prinsip metode Venturini dapat dijelaskan pada awalnya menggunakan keluaran fase tunggal. Tegangan keluaran tiga fase dihasilkan oleh tiga rangkaian independen, dan persamaan analitik untuk ketiga bentuk gelombang memiliki karakteristik yang sama (Kandan, Senthilkumar \& Dhivya, 2016). Pola switching hasil dari perencanaan dan pengujian metode Venturini dapat dilihat pada Gambar 8. 


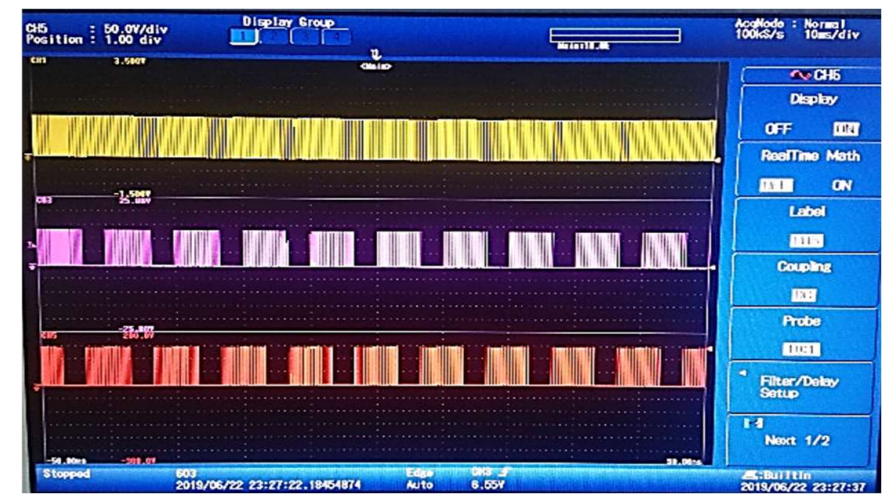

(a)

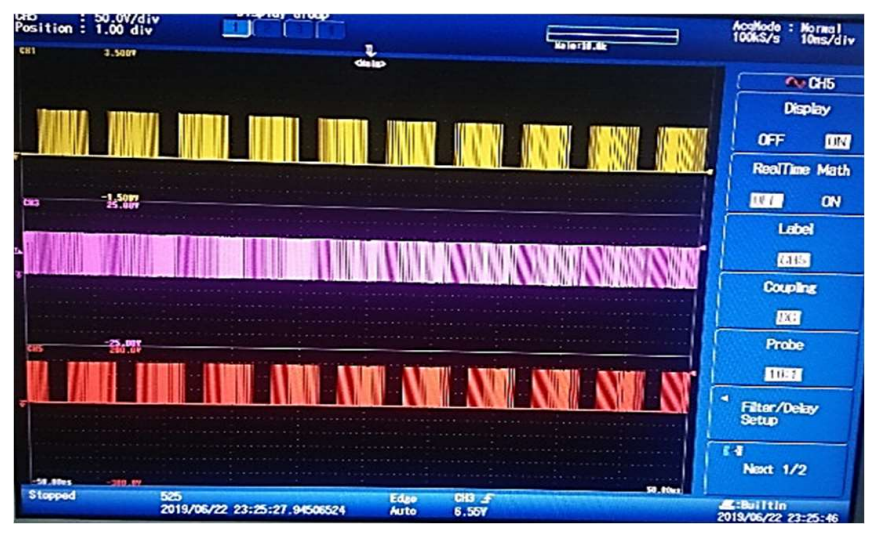

(b)

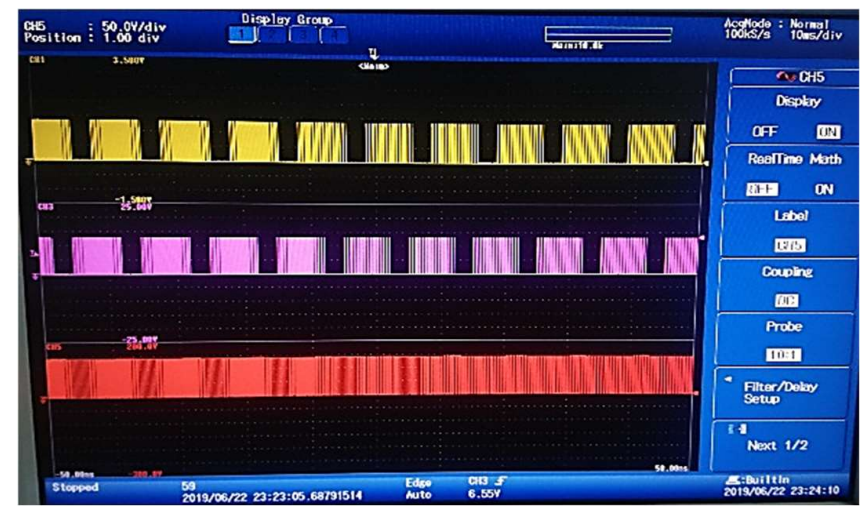

(c)

Gambar 8. Modulasi Switching $S_{11}, S_{12}$ dan $S_{13} ;$ Modulasi Switching $S_{21}, S_{22}$ dan $S_{23}$; Modulasi Switching $S_{31}$, $S_{32}$ dan $S_{33}$

Elemen switching S1-S9 adalah sakelar bidirectiona/ yang menghubungkan fase keluaran ke salah satu dari tiga fase masukan dan dioperasikan sesuai dengan pola switching yang ditunjukkan pada Gambar 8. Hanya satu dari tiga sakelar yang dihubungkan pada waktu tertentu, dan ini memastikan bahwa masukan matrix converter, yang merupakan sumber tegangan, tidak terhubung singkat sementara arus kontinyu disuplai ke beban (Kandan, Senthilkumar \& Dhivya, 2016). 


\subsection{Pengujian Direct Matrix Converter pada Motor Induksi 3 Fase}

Direct matrix converter adalah salah satu jenis AC - AC converter dimana antara sisi tegangan masukan terhubung langsung ke sisi tegangan keluaran tanpa membutuhkan elemen penyimpapan energi (Rodriguez, dkk, 2012). Oleh karena matrix converter adalah jenis direct AC -AC converter, sehingga dibutuhkan suatu sakelar bidirectional yang dapat mengalirkan arus secara dua arah. Maka pada makalah ini telah dilakukan perencanaan dan pengujian direct matrix converter yang tersusun dari 9 sakelar bidirectiona/ menggunakan 18 buah MOSFET tipe IXFH 60N60 yang disusun secara berkebalikan antar MOSFET. Motor induksi 3 fase yang digunakan mempunyai kapasitas daya 0,375 kW. Gambar dari hardware direct matrix converter ditunjukkan oleh Gambar 9.

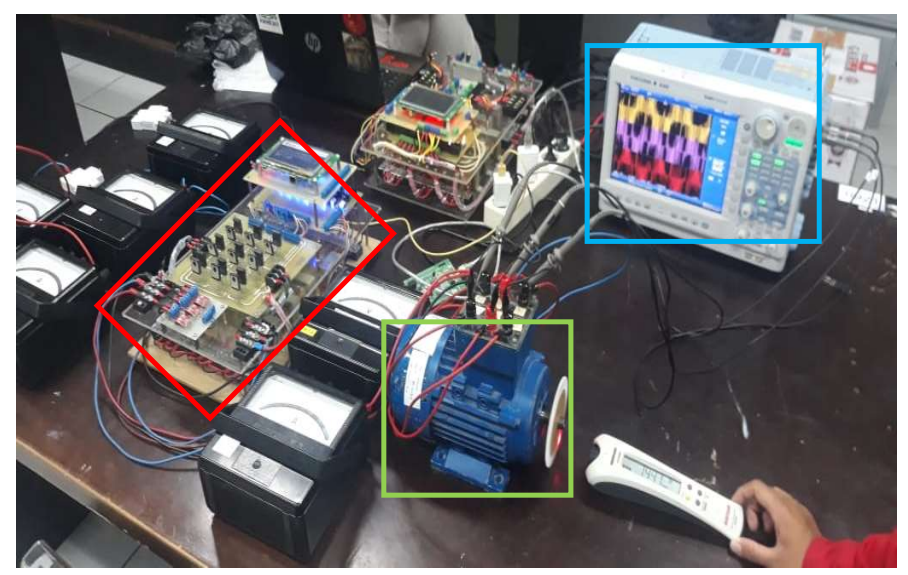

Gambar 9. Hardware Direct Matrix Converter

Keterangan : $\square$ direct matrix converter

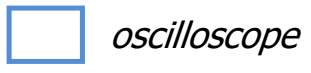

$\square$ motor induksi 3 fase

Pengujian ini dilakukan dengan memberikan suplai tegangan masukan 3 fase pada direct matrix converter dan keluaran konverter terhubung langsung ke beban motor induksi 3 fase. Direct matrix converter menggunakan metode Venturini untuk teknik modulasinya dilakukan dengan perhitungan matematis untuk menghasilkan sinyal PWM pada 9 sakelar bidirectional. Sinyal PWM metode Venturini dihasilkan dari sebuah mikrokontroller ARM STM32 F407VGTX, dimana keluaran dari pin mikrokontroller berupa sinyal PWM yang sudah dimodulasi. Kemudian pin keluaran dari mikorokontroller dihubungkan ke rangkaian driver MOSFET untuk proses penguatan sinyal PWM yang sudah dimodulasi. Keluaran rangkaian driver MOSFET dihubungkan ke kaki Gate dari MOSFET. Dari uraian tersebut akan menghasilkan gelombang keluaran dari Direct Matrix Converter menggunakan metode Venturini yang frekuensi keluaran dari converter bisa diubah untuk mengendalikan kecepatan motor induksi 3 fase. Hasil dari pengujian bentuk gelombang keluaran dari direct matrix converter ditunjukkan pada Gambar 10. 


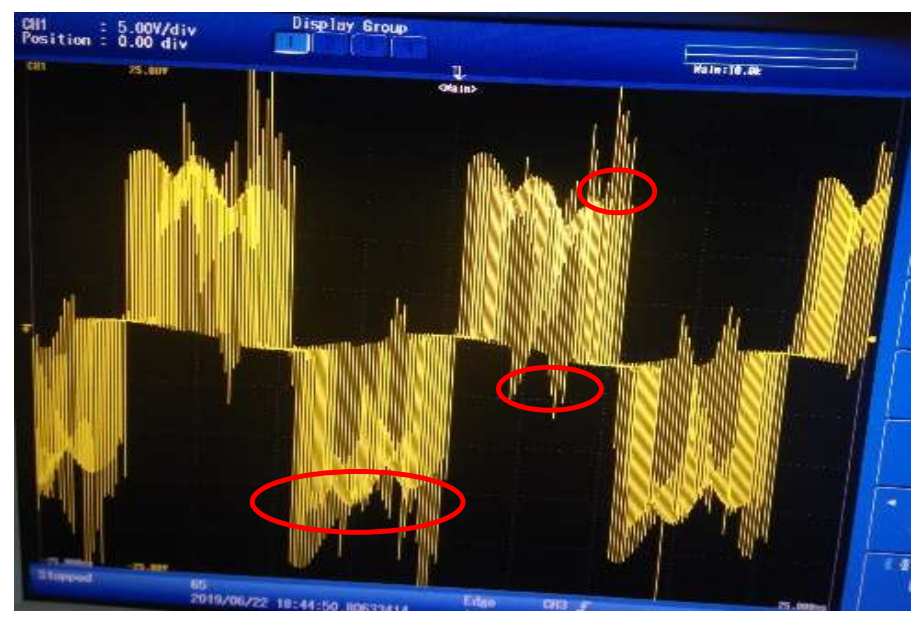

\section{Gambar 10. Gelombang Keluaran Direct Matrix Converter}

Keterangan:

spike tegangan

Gambar 10 adalah bentuk gelombang keluaran dari direct matrix converter. Gelombang keluaran tersebut jika dibandingkan dengan hasil perencanaan dari simulasi, bentuk gelombangnya mendekati dari hasil simulasi. Tetapi terlihat jelas bahwa pada Gambar 10 bentuk gelombang keluarannya terdapat spike tegangan yang dapat membahayakan komponen dari konverter itu sendiri maupun beban yang disuplai. Spike tegangan yang terjadi disebabkan salah satunya karena faktor komponen yang digunakan terutama komponen MOSFET, dimana dalam keadaan tanpa terhubung ke beban gelombang keluaran dari MOSFET sudah ada spike tegangannya. Sehingga dengan faktor ini gelombang keluaran mengalami kecacatan bentuk gelombang. Sementara itu data untuk hasil pengujian direct matrix converterpada beban motor induksi 3 fase dengan kecepatan nominal dapat dilihat pada Tabel 3.

Tabel 3. Data Pengujian Kecepatan Nominal Motor Induksi $\left(f_{\text {out }}=50 \mathrm{~Hz}\right)$

\begin{tabular}{|c|c|c|c|c|}
\hline $\begin{array}{c}\text { Vin } \\
\text { (Volt) }\end{array}$ & $\begin{array}{c}\text { Iin } \\
\text { (Ampere) }\end{array}$ & $\begin{array}{c}\text { Vout } \\
\text { (Volt) }\end{array}$ & $\begin{array}{c}\text { Iout } \\
\text { (Ampere) }\end{array}$ & $\begin{array}{c}\text { n } \\
\text { (Rpm) }\end{array}$ \\
\hline 0 & 0 & 0 & 0 & 0 \\
\hline 10 & 0,1 & 0 & 0 & 0 \\
\hline 20 & 0,1 & 10 & 0,2 & 0 \\
\hline 30 & 0,5 & 22 & 0,55 & 320 \\
\hline 40 & 0,5 & 30 & 0,5 & 1253 \\
\hline 50 & 0,5 & 36 & 0,5 & 1364 \\
\hline 60 & 0,5 & 46 & 0,55 & 1403 \\
\hline 70 & 0,55 & 52 & 0,55 & 1438 \\
\hline 80 & 0,55 & 60 & 0,6 & 1443 \\
\hline 90 & 0,6 & 67 & 0,6 & 1444 \\
\hline 100 & 0,6 & 72 & 0,6 & 1446 \\
\hline
\end{tabular}

Dari Tabel 3 dapat dilihat bahwa saat tegangan masukan sebesar 10V dan 20V motor induksi belum berputar dikarenakan tegangan keluaran dari direct matrix converter belum mampu 
untuk melakukan starting pada motor induksi. Pada saat tegangan masukan sebesar 30V, motor mulai berputar dengan kecepatan sangat rendah yaitu 320 Rpm karena masih dalam proses starting. Pada pengujian ini motor mulai berada pada kondisi steady saat tegangan masukan sebesar 70V dengan kecepatan motor sebesar 1438 Rpm. Pengujian ini diambil dengan step 10V dari 0V hingga 100V, hal ini dikarenakan adanya keterbatasan dari kemampuan hardware (MOSFET).

Sementara itu, pada pengujian ini juga dilakukan percobaan pada saat motor berputar dibawah frekuensi nominalnya yaitu dengan frekuensi keluaran sebesar $40 \mathrm{~Hz}$. Pengujian ini bertujuan untuk mengendalikan kecepatan motor induksi 3 fase mencapai kecepatan putar sebesar $1200 \mathrm{Rpm}$. Sesuai dengan rumus kecepatan dari motor induksi yaitu $n_{s}=\frac{120 \times f}{P}$ dengan motor induksi yang digunakan memiliki kutub (Pole) sebanyak 4 buah, maka untuk mencapai kecepatan motor sebesar 1200 Rpm direct matrix converter harus mengeluarkan tegangan dengan frekuensi sebesar $40 \mathrm{~Hz}$. Dalam pengujian ini direct matrix converter akan merubah frekuensi dari modulasi tegangan menuju $40 \mathrm{~Hz}$ untuk dapat menghasilkan tegangan keluaran dengan frekuensi sebesar $40 \mathrm{~Hz}$. Data hasil pengujian kecepatan motor dengan $\mathrm{f}=$ $40 \mathrm{~Hz}$ dapat dilihat pada Tabel 4.

Tabel 4. Data pengujian Kecepatan Nominal Motor Induksi ( $f_{\text {out }}=\mathbf{4 0} \mathrm{Hz}$ )

\begin{tabular}{|c|c|c|c|c|}
\hline $\begin{array}{c}\text { Vin } \\
\text { (Volt) }\end{array}$ & $\begin{array}{c}\text { Iin } \\
\text { (Ampere) }\end{array}$ & $\begin{array}{c}\text { Vout } \\
\text { (Volt) }\end{array}$ & $\begin{array}{c}\text { Iout } \\
\text { (Ampere) }\end{array}$ & $\begin{array}{c}\mathbf{n} \\
\text { (Rpm) }\end{array}$ \\
\hline 0 & 0 & 0 & 0 & 0 \\
\hline 10 & 0,1 & 0 & 0 & 0 \\
\hline 20 & 0,2 & 15 & 0,2 & 0 \\
\hline 30 & 0,5 & 22 & 0,5 & 170 \\
\hline 40 & 0,55 & 30 & 0,5 & 678 \\
\hline 50 & 0,55 & 34 & 0,55 & 958 \\
\hline 60 & 0,6 & 42 & 0,6 & 1050 \\
\hline 70 & 0,65 & 48 & 0,6 & 1090 \\
\hline 80 & 0,7 & 55 & 0,75 & 1100 \\
\hline 90 & 0,7 & 60 & 0,8 & 1123 \\
\hline
\end{tabular}

Dari Tabel 4 dapat dilihat bahwa saat tegangan masukan sebesar $10 \mathrm{~V}$ dan $20 \mathrm{~V}$ motor induksi belum berputar dikarenakan tegangan keluaran dari matrix converter belum mampu untuk melakukan starting pada motor induksi. Pada saat tegangan masukan sebesar 30V, motor mulai berputar dengan kecepatan sangat rendah yaitu $170 \mathrm{Rpm}$ karena masih dalam proses starting. Pada pengujian ini motor mulai berada pada kondisi steady saat tegangan masukan sebesar 90V dengan kecepatan motor sebesar 1123 Rpm. Sementara itu, respon kecepatan pada saat frekuensi keluaran dari direct matrix converter sebesar $50 \mathrm{~Hz}$ dab $40 \mathrm{~Hz}$ ditunjukkan pada Gambar 11. 


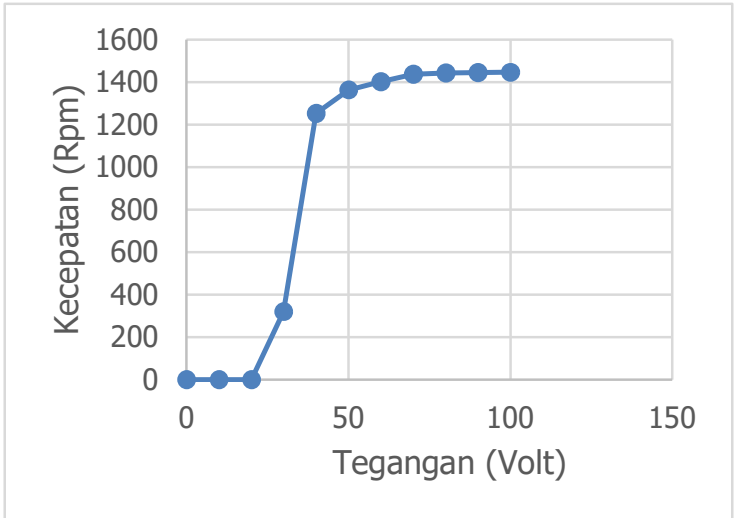

(a)

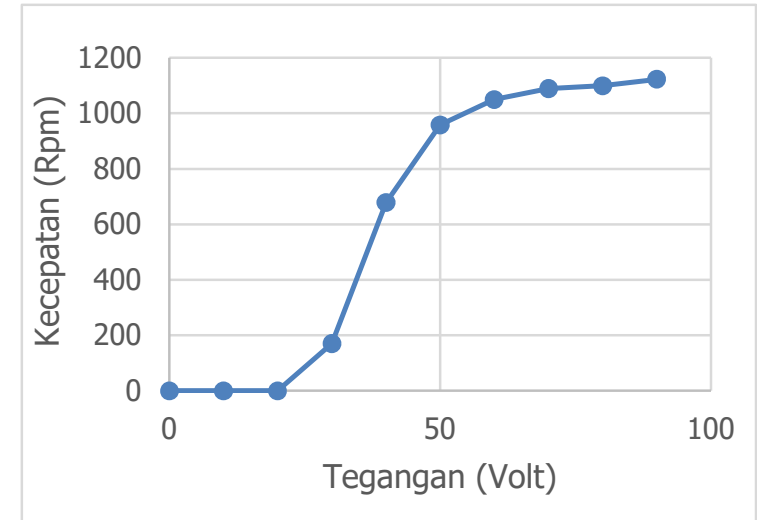

(b)

Gambar 11. Respon Kecepatan Motor Induksi (a) $f_{\text {out }}=50 \mathrm{~Hz}$, (b) $f_{\text {out }}=40 \mathrm{~Hz}$

Pengujian direct matrix converter yang telah dilakukan hasilnya ditunjukkan pada Tabel 3 dan Tabel 4, sementara tanggapan dari perubahan frekuensi terhadap kecepatan ditunjukkan pada Gambar 11. Pada pengujian direct matrix converter untuk pengendalian kecepatan motor induksi, sistem yang dirancang dapat bekerja sesuai dengan perencanaan yang telah dibuat yaitu kecepatan motor induksi dapat berubah seiring dengan berubahnya frekuensi keluaran dari direct matrix converter. Perubahan kecepatan yang diinginkan adalah beoperasi pada kecepatan nominal dan dibawah kecepatan nominal. Tanggapan pada saat frekuensi nominal memilki tanggapan rise time yang lebih cepat untuk mencapai kecepatan nominal daripada tanggapan pada saat dibawah frekuensi nominal.

Sementara itu, efisiensi yang bagus, losses yang rendah pada pengendalian kecepatan motor induksi erat hubungannya dengan kandungan harmonisa yang dihasilkan oleh jenis konverter yang digunakan untuk teknik kendalinya. Penggunaan direct matrix converter pada pengujian yang sudah dilakukan dilihat kandungan harmonisanya menggunakan sebuah alat fluke meter seperti yang ditunjukkan pada Gambar 12.

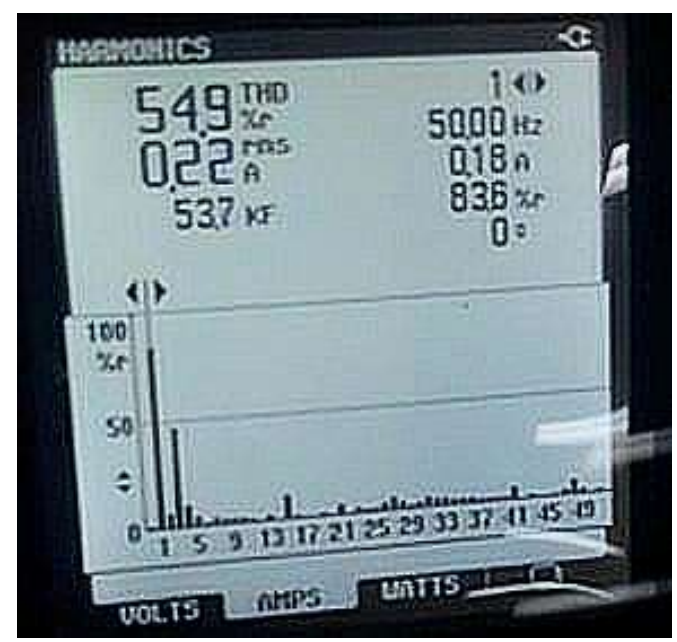

Gambar 12. Spektrum Harmonisa Metode Venturini $f_{o}=50 ~ H z$ 
Aplikasi Direct Matrix Converter pada Pengendali Kecepatan Motor Induksi 3 Fase menggunakan Modulasi Venturini

Pada Gambar 12 adalah spektrum harmonisa yang dihasilkan direct matrix converter menggunakan metode Venturini. Nilai harmonisa pada masing - masing orde ditunjukkan pada Tabel 5.

Tabel 5. Nilai Harmonisa (\%) pada Frekuensi Nominal $f_{o}=50 \mathrm{~Hz}$

\begin{tabular}{|c|c|c|c|}
\hline \multirow{2}{*}{$\begin{array}{c}\text { Frekuensi dari } \\
\text { tegangan keluaran }\end{array}$} & $\begin{array}{c}\text { Orde harmonisa } \\
\text { ketiga (\%) }\end{array}$ & $\begin{array}{c}\text { Orde harmonisa } \\
\text { kelima (\%) }\end{array}$ & $\begin{array}{c}\text { Orde harmonisa } \\
\text { ketujuh (\%) }\end{array}$ \\
\cline { 2 - 4 } & $50 \mathrm{~Hz}$ & $50 \mathrm{~Hz}$ & $50 \mathrm{~Hz}$ \\
\hline Meotde Venturini & 45,83 & 4,56 & 1,27 \\
\hline
\end{tabular}

Pada Tabel 5 dapat dilihat bahwa orde harmonisa ke 3 nilainya masih cukup tinggi dengan nilai $45,83 \%$, namun pada harmonisa kelima, ketujuh dan orde harmonisa kelipatan ganjil yang lain nilainya sudah kecil $\mathrm{I}_{\mathrm{h} 5}=4,56 \%$ dan $\mathrm{I}_{\mathrm{h} 7}=1,27 \%$. Pada sistem direct matrix converter yang dirancang menggunakan metode Venturini berdasar nilai kandungan harmonisanya menghasilkan niali yang cukup bagus karena persentase harmonisa masih dibawah nilai yang diperbolehkan yaitu untuk arus nilainya adalah $<10 \%$. Harmonisa erat hubungannya dengan efisiensi dan losses yang dihasilkan, sehingga pada sistem pengendalian motor induksi menggunakan direct matrix converter bisa dikatakan menghasilkan losses yang tidak terlalu tinggi dan efisiensi yang cukup bagus karena nilai harmonisa arusnya $<10 \%$.

\section{KESIMPULAN}

Suatu sistem AC - AC converter yang dirancang adalah aplikasi direct matrix converter yang tersusun dari 9 sakelar bidirectional dengan menggunakan MOSFET sebagai komponen utamanya. Teknik modulasi yang digunakan pada direct matrix converter adalah modulasi Venturini atau pendekatan direct transfer function. Sinyal PWM yang digunakan dihitung secara matematis menggunakan metode Venturini untuk menghasilkan frekuensi tetap maupun tegangan tetap dan frekuensi berubah. Keluaran dari direct matrix converter terhubung langsung ke beban motor induksi 3 fase, sehingga dengan mengubah frekuensi dari modulasi tegangan menggunakan metode Venturini, akan terjadi perubahan kecepatan dari motor induksi. Dari hasil pengujian didapatkan bahwa direct matrix converter mampu menghasilkan perubahan frekuensi keluaran, sehingga menyebabkan motor induksi berputar sesuai dengan frekuensi keluaran yang dihasilkan dari direct matrix converter. Pada pengujian dengan frekuensi keluaran sebesar $50 \mathrm{~Hz}$ motor mulai berada pada kondisi steady saat tegangan masukan sebesar 70V dengan kecepatan motor sebesar $1438 \mathrm{Rpm}$. Sedangkan pada saat frekuensi keluaran diubah sebesar $40 \mathrm{~Hz}$ motor mulai berada pada kondisi steady saat tegangan masukan sebesar 90V dengan kecepatan motor sebesar $1123 \mathrm{Rpm}$. Dari keseluruhan pengujian direct matrix converter menggunakan metode Venturini pada motor induksi 3 fase menghasilkan harmonisa yang nilainya cukup tinggi pada Ih $3=45,83 \%$ dan nilai yangf relatif kecil pada Ih5 $=4,56 \%$ dan Ih7 $=1,27 \%$.

\section{DAFTAR RUJUKAN}

Bachir, G., \& Bendiabdellah, A. (2009). Scalar Control for a Matrix Converter. Acta Electrotechnica et Informatica, 9(2), 38 -43.

Fujisaki, K., Sakai, M., \& Takeda, S. (2012). Motor loss increment of induction motor driven by pwm inverter in comparison with inverter circuit loss. International Conference on 
Electrical Machines and Systems (ICEMS), (pp. 1 - 6).

Hamane, B, Doumbia, M. L. , Cheriti, A., \& Belmokhtar, K. (2014). Comparative Analysis of PI and Fuzzy Logic Controllers for Matrix Converter. Ninth International Conference on Ecological Vehicles and Renewable Energies, (pp. 16 - 32).

Hannan, M. A., Ali, J. A., Mohamed, A., \& Hussain, A. (2017). Optimization Techniques to Enhance the Performance of Induction Motor Drives: A Review. Renewable and Sustainable Energy Reviews, 1-16.

Kandan, K., Senthilkumar, K., \& Dhivya, K. (2016). Total Harmonic Distortion Analysis of Matrix Converter. International Journal of Multidisciplinary Research and Modern Education (IJMRME), 2(2), $174-182$.

Karaca, H., \& Akkaya, R. (2012). Modeling, Simulation and Analysis of Matrix Converter Using Matlab\&Simulink. International Journal of Modeling and Optimazation, 2(3), 328 -332.

Mahendran, N., \& Gurusamy, Dr.G. (2010). Fuzzy Controller for Matrix Converter System to Improve its Quality Output. International Journal of Artificial Intelligence \& Applications (IJAIA), 1(4), $17-27$.

Metidji, B., Taib, N., Baghli, L., Rekioua, T., \& Bacha, S. (2013). Novel Single Current Sensor Topology for Venturini Controlled Direct Matrix Converters. IEEE Transactions on Power Electronics, 28(7), 3509 -3516.

Rezaoui, M. M., Kouzou, A., Lazhari, N., \& Mahmoudian, M. O. (2013). Comparative analysis of PWM strategies of Venturini and Roy for the control of a [3×3] matrix converter. International Journal of Advanced Renewable Energy Research, 2(2), 681-688.

Riba, J. R., Torres, C. L., Romeral, L., \& Garcia, A. (2016). Rare-Earth-Free Propulsion Motors for Electric Vehicles: A Technology Review. Renewable and Sustainable Energy Reviews, 57, 367-79.

Rodriguez, J., Rivera, M., Kolar, J. W., \& Wheeler, P. W. (2012). A Review of Control and Modulation Methods for Matrix Converters. IEEE Transactions on Industrial Electronics, 59(1), 58-70.

Roy, R. B., Cros, J., Basher, E., \& Taslim, S. Md. B. (2017). Fuzzy Logic Based Matrix Converter Controlled Indution Motor Drive. IEEE Region 10 Humanitarian Technology Conference (R10-HTC), (pp. $21-23)$. 